\title{
PENERAPAN MODEL PEMBELAJARAN KOOPERATIF TIPE THINK-PAIR-SHARE (TPS) UNTUK MENINGKATKAN HASIL BELAJAR PKN SISWA KELAS III SD NEGERI 2 LALOEHA KABUPATEN KOLAKA
}

\author{
Nurwahida $^{1)}$, La Ode Safiun Arihi ${ }^{1)}$, Sakka Hasan ${ }^{1)}$ \\ ${ }^{1)}$ Jurusan Pendidikan Guru Sekolah Dasar \\ FKIP Universitas Halu Oleo \\ email: nurwahida.pij@gmail.com
}

\begin{abstract}
Abstrak: Rumusan masalah dalam penelitian ini adalah apakah penerapan model pembelajaran kooperatif tipe Think-Pair-Share (TPS) dapat meningkatkan aktivitas mengajar guru, aktivitas belajar siswa dan hasil belajar siswa kelas III SD Negeri 2 Laloeha? Tujuan penelitian ini adalah untuk meningkatkan aktivitas mengajar guru, aktivitas belajar siswa dan hasil belajar siswa PKn kelas III SD Negeri 2 Laloeha dengan menggunakan model pembelajaran kooperatif tipe ThinkPair-Share (TPS) pada materi norma yang berlaku di masyarakat. Jenis penelitian ini adalah Penelitian Tindakan Kelas (PTK). Adapun prosedur penelitian ini adalah : (1) perencanaan; (2) pelaksanaan tindakan; (3) observasi; (4) evaluasi; (5) refleksi. Sumber data dalam penelitian ini adalah guru dan siswa. Hasil analisis penelitian menunjukkan ketuntasan hasil belajar siswa pada siklus I mencapai 10 orang atau sebesar $62,5 \%$ dengan nilai rata-rata 66,25 , persentase aktivitas guru pertemuan pertama sebesar $64,7 \%$ dan pertemuan kedua sebesar $76,5 \%$, persentase aktivitas belajar siswa pertemuan pertama sebesar $58,8 \%$ dan pertemuan kedua sebesar $76,5 \%$. Pada siklus II ketuntasan hasil belajar siswa mencapai 15 orang atau sebesar $93,75 \%$ dengan nilai rata-rata 72,3 , persentase aktivitas guru sebesar $88,2 \%$, persentase aktivitas belajar siswa sebesar $82,4 \%$. Kesimpulan dari penelitian ini adalah penerapan model pembelajaran kooperatif tipe TPS dapat meningkatkan hasil belajar PKn siswa, persentase aktivitas mengajar guru dan persentase aktivivtas belajar siswa di kelas III SD Negeri 2 Laloeha Kabupaten Kolaka.
\end{abstract}

\section{Kata kunci: Model pembelajaran, Think-Pair-Share, hasil belajar}

Abstract: The formulation of the problem in this research is whether the application of the ThinkPair-Share (TPS) type of cooperative learning model can improve teacher teaching activities, student learning activities and learning outcomes of third grade students of SD Negeri 2 Laloeha? The purpose of this study was to improve teacher teaching activities, student learning activities and learning outcomes of PKn students in class III of SD Negeri 2 Laloeha by using the Think-PairShare (TPS) type of cooperative learning model on norms that apply in the community. This type of research is Classroom Action Research (CAR). The procedures of this study are: (1) planning; (2) implementing actions; (3) observation; (4) evaluation; (5) reflection. Data sources in this study are teachers and students. The results of the research analysis showed the completeness of student learning outcomes in the first cycle reached 10 people or at $62.5 \%$ with an average value of 66.25 , the percentage of teacher activity at the first meeting was $64.7 \%$ and the second meeting at $76.5 \%$, the percentage of activities first meeting student learning by $58.8 \%$ and second meeting by $76.5 \%$. In the second cycle completeness student learning outcomes reached 15 people or $93.75 \%$ with an average value of 72.3 , the percentage of teacher activity by $88.2 \%$, the percentage of student learning activities by $82.4 \%$. The conclusion of this study is the application of the type of TPS cooperative learning model can improve student learning outcomes PKn, the percentage of teacher teaching activities and the percentage of student learning activities in class III SD Negeri 2 Laloeha, Kolaka Regency.

Keywords: Learning model, Think-Pair-Share, learning outcomes 


\section{Pendahuluan}

Pendidikan adalah salah satu perwujudan kebudayaan manusia yang dinamis dan sarat perkembangan. Oleh karena itu perubahan atau perkembangan pendidikan adalah hal yang memang seharusnya terjadi sejalan dengan perubahan budaya kehidupan. Perubahan dalam arti perbaikan pendidikan pada semua tingkat perlu terus menerus dilakukan sebagai antisipasi kepentingan masa depan dan tuntutan masyarakat moderen. Salah satu ciri masyarakat moderen adalah selalu ingin terjadinya perubahan yang lebih baik. Hal ini tentu saja menyangkut berbagai bidang pendidikan. Komponen yang melekat pada pendidikan diantaranya adalah kurikulum, guru dan siswa. Dalam proses pembelajaran keberadaan guru sangatlah urgen karena guru sebagai penentu tercapainya tujuan pembelajaran (Amri, 2013:1).

Guru memegang peranan penting dalam meningkatkan mutu dan proses pembelajaran melalui penerapan model pembelajaran yang tepat. Penerapan model pembelajaran yang tidak tepat menjadikan mutu dan kualitas proses pembelajaran di sekolah kurang memuaskan. Untuk itu perlu adanya inovasi berbagai strategi pendekatan agar proses pembelajaran efektif dan menyenangkan sehingga tujuan utama peningkatan mutu pendidikan dapat dicapai secara optimal. Seperti informasi dari hasil observasi peneliti, hasil belajar siswa di tingkat sekolah dasar khususnya SD Negeri 2 Laloeha masih memprihatinkan karena berada di bawah standar kriteria ketuntasan minimal (KKM) yang ditetapkan di sekolah. Kondisi ini juga terjadi pada mata pelajaran PKn materi Norma yang Berlaku di Masyarakat di kelas III SD Negeri 2 Laloeha dengan hasil belajar siswa masih di bawah KKM yang ditetapkan sekolah yakni 70. Nilai rata-rata siswa pada materi Norma yang Berlaku di Masyarakat pada semester ganjil tahun pelajaran 2015/2016 nilai rata-rata materi Norma yang Berlaku di Masyarakat adalah 65 dengan persentase ketuntasan hanya mencapai $60 \%$.

Berdasarkan pada uraian di atas penulis merasa tertarik untuk menerapkan salah satu model pembelajaran sebagai suatu alternatif utuk meningkatkan hasil belajar PKn siswa. Model pembelajaran yang dimaksud adalah model pembelajaran kooperatif tipe Think-Pair-Share (TPS).

Beberapa hal yang menjadi alasan dalam pemilihan alternatif ini adalah bahwa model pembelajaran kooperatif tipe TPS ini merupakan model pembelajaran kooperatif yang dapat memberikan waktu khusus bagi siswa untuk berpikir secara mandiri sebelum berdiskusi dengan pasangannya. Hal ini memungkinkan siswa untuk menyalurkan pendapatnya secara optimal, siswa juga menjadi lebih bertanggung jawab dalam memahami materi pelajaran karena dituntut untuk memiliki jawaban/pendapat sendiri sebelum berbagi pendapat dengan teman kelompoknya.

Dari beberapa uraian di atas, maka penulis merasa tertarik untuk mengadakan suatu penelitian mengenai peningkatan hasil belajar PKn. Bentuk penelitian yang dimaksud yaitu penelitian tindakan kelas dan dirumuskan dalam suatu judul: "Penerapan Model Pembelajaran Kooperatif Tipe Think-Pair-Share (TPS) untuk Meningkatkan Hasil Belajar PKn Siswa Kelas III SD Negeri 2 Laloeha Kabupaten Kolaka".

Hasil penelitian yang relevan dilakukan oleh Hartina (2010) melakukan penelitian dengan judul Upaya Meningkatkan Hasil Belajar PKn Siswa Kelas IV SD Negeri Lalombaa Pada Materi Sistem Pemerintahan Kabupaten dan Kota Melalui Penerapan Pembelajaran Kooperatif Tipe TPS. Dalam penelitiannya menarik kesimpulan bahwa penerapan Pembelajaran Kooperatif Tipe TPS Meningkatkan Hasil Belajar PKn Siswa Kelas IV SD Negeri Lalombaa. Peningkatan hasil belajar siswa terlihat dari persentase ketuntasan hasil belajar pada siklus I mencapai $70 \%$ dengan rata-rata 65 dan pada siklus II persentase ketuntasan hasil belajar meningkat menjadi $90 \%$ dengan rata-rata 78, serta Wa Ode Siti Nawariah (2014) melakukan penelitian dengan judul Penerapan Model Pembelajaran Kooperatif Tipe Think-Pair-Share (TPS) untuk Meningkatkan Hasil Belajar PKn Siswa pada Materi Keputusan Bersama di Kelas III SD Negeri 05 Kendari Barat. Pada siklus I ketuntasan hasil belajar mencapai $70 \%$ sedangkan pada siklus II persentase ketuntasan hasil belajar meningkat menjadi 90\%. Disimpulkan bahwa penerapan pembelajaran kooperatif tipe TPS meningkatkan hasil belajar PKn siswa pada materi keputusan bersama di kelas III SD Negeri 05 Kendari Barat.

masalah dalam penelitian ini adalah apakah penerapan model pembelajaran kooperatif tipe Think-Pair-Share (TPS) dapat meningkatkan aktivitas mengajar guru, aktivitas belajar siswa dan hasil belajar siswa kelas III SD Negeri 2 Laloeha? Tujuan penelitian ini adalah untuk meningkatkan 
aktivitas mengajar guru, aktivitas belajar siswa dan hasil belajar siswa PKn kelas III SD Negeri 2 Laloeha dengan menggunakan model pembelajaran kooperatif tipe Think-Pair-Share (TPS) pada materi norma yang berlaku di masyarakat.

\section{Metode Penelitian}

Jenis penelitian adalah Penelitian Tindakan Kelas (PTK). Penelitian ini telah dilaksanakan pada semester ganjil, tahun pelajaran 2016/2017 di kelas III SD Negeri 2 Laloeha Kabupaten Kolaka. Penelitian dilaksanakan dalam dua siklus tindakan. Subyek penelitian ini adalah guru dan siswa di SD Negeri 2 Laloeha, dimana siswanya berjumlah 20 orang yang terdiri dari 12 siswa perempuan dan 8 siswa laki-laki. Beberapa faktor yang diteliti adalah:

1. Faktor aktivitas guru, yaitu melihat aktivitas guru dalam menyajikan materi pelajaran dengan menerapkan model pembelajaran koperatif tipe Think-Pair-Share (TPS).

2. Faktor aktivitas siswa, yaitu melihat aktivitas belajar siswa selama proses pembelajaran dengan penerapan model pembelajaran kooperatif tipe TPS.

3. Faktor hasil belajar siswa yaitu melihat hasil dan ketuntasan belajar siswa dalam mempelajari materi yang diajarkan setelah penerapan model pembelajaran kooperatif tipe TPS.

Prosedur yang ditempuh dalam penelitian ini mencakup yaitu: (1) tahap perencanaan (planning); (2) tahap pelaksanaan tindakan (action); (3) tahap observasi dan tahap evaluasi (observation and evaluation); (4) tahap refleksi (reflection). Data dalam penelitian ini adalah data kualitatif berupa kegiatan proses pembelajaran aktivitas belajar siswa dan aktivitas guru, dan data kuantitatif berupa nilai hasil belajar siswa. Sumber data penelitian ini adalah siswa kelas III SD Negeri 2 Laloeha berupa nilai hasil belajar siswa dan guru berupa hasil observasi dalam menerapkan model pembelajaran kooperatif tipe TPS.

Analisis data dalam penelitian ini adalah menggunakan statistik deskriptif untuk menghitung nilai siswa, rata-rata nilai siswa, dan ketuntasan belajar siswa.

1. Menentukan Nilai Siswa

Nilai siswa ditentukan berdasarkan skor yang diperoleh siswa pada tes yang dilakukan dengan rumus:

$$
\text { Nilai Siswa }=\frac{\text { Skor Perolehan Siswa }}{\text { Skor Maksimum }} \times 100
$$

2. Menentukan Rata-Rata Nilai Siswa

$$
\bar{X}=\frac{\sum x i}{n}
$$

Ket. $\quad n \quad$ : Jumlah siswa secara keseluruhan

(Suparno, 2008:81)

$\bar{X} \quad$ : Nilai rerata yang diperoleh siswa

$\sum^{-} x i \quad$ Jumlah nilai yang diperoleh setiap siswa

3. Menentukan ketuntasan belajar

a. Ketuntasan Individu

Ketuntasan individu siswa ditentukan berdasarkan nilai yang diperoleh pada setiap siklus. Siswa dikatakan belajar tuntas jika nilai yang diperoleh siswa adalah $\geq 70$ sesuai KKM yang ditetapkan sekolah. 
b. Ketuntasan Klasikal

Ketuntasan klasikal ditentukan berdasarkan persentase ketuntasan individu siswa pada setiap siklus pembelajaran dengan rumus sebagai berikut.

$$
\% \text { tuntas }=\frac{\sum f i}{n} \times 100 \%
$$

Dengan :

$$
\begin{array}{ll}
\mathrm{n} & : \text { Jumlah siswa secara keseluruhan } \\
\sum f i & \text { : Jumlah siswa pada kategori ketuntasan belajar }
\end{array}
$$

(Suparno, 2008:82)

Indikator keberhasilan dalam penelitian ini adalah hasil belajar PKn pada materi pokok Norma yang Berlaku di Masyarakat dikatakan tuntas apabila minimal $80 \%$ siswa telah memperoleh nilai $\geq 70$ sesuai Kreteria Ketuntasan Minimal (KKM) yang ditetapkan di SD Negeri 2 Laloeha Kabupaten Kolaka.

\section{Hasil Penelitian}

Peneliti melakukan observasi di kelas III SD Negeri 2 Laloeha untuk memperoleh informasi yang masalah penyebab rendahnya persentase ketuntasan hasil belajar siswa. Hasil observasi menunjukkan bahwa guru dalam menyajikan materi tidak memberikan kesempatan kepada siswa untuk memperoleh pemahaman melalui potensi yang dimilikinya. Hal ini berdampak pada rendahnya hasil belajar siswa dengan ketuntasan hasil belajar siswa pada semester ganjil tahun 2015/2016 sebesar yang menunjukan bahwa ketuntasan hasil belajar siswa masih berada dibawah kriteria ketuntasan minimal (KKM) yang ditetapkan sekolah yang mengharuskan siswa memperoleh nilai $\geq 70$.

\section{Aktivitas Guru Selama KBM}

Aktivitas guru selama kegiatan pembelajaran berlangsung diamati oleh observer dengan menggunakan lembar observasi aktivitas guru. Aktivitas yang diamati pada guru menyangkut pelaksanaan model pembelajaran berupa kegiatan pendahuluan, kegiataan inti dan penutup. Hasil observasi aktivitas guru siklus I dapat dilihat pada gambar grafik berikut:

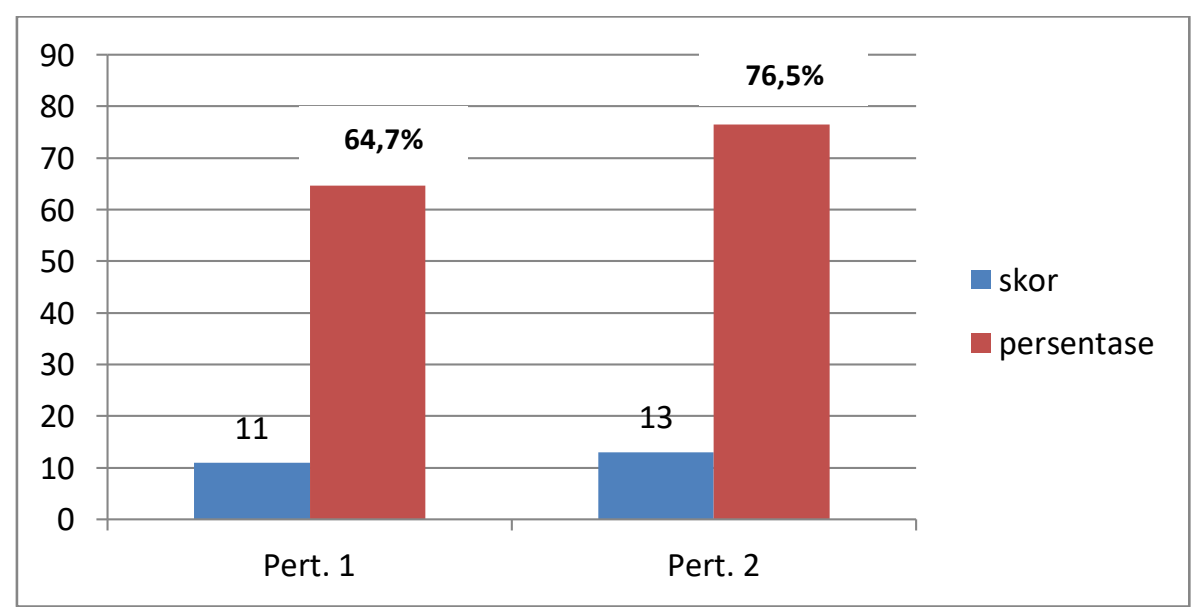

Gambar 1. Hasil Observasi Aktivitas Guru Siklus I

Berdasarkan grafik di atas, dapat dijelaskan bahwa aktivitas guru dalam menerapkan model pembelajaran dari 17 skor pada pertemuan pertama mencapai skor 11 atau sebesar 64,7\% sedangkan pada pertemuan kedua mencapai skor 13 atau sebesar 76,5\%. Hal ini menunjukkan bahwa aktivitas guru dalam KBM dari pertemuan pertama mengalami peningkatan pada pertemuan kedua.

Hasil observasi aktivitas guru siklus II dapat dilihat pada gambar grafik berikut: 
Jurnal Ilmiah Pembelajaran Sekolah Dasar

Volume 1 Nomor 2 - Agustus 2019,e-ISSN 26560402

Available online at:http://ojs.uho.ac.id/index.php/jipsd

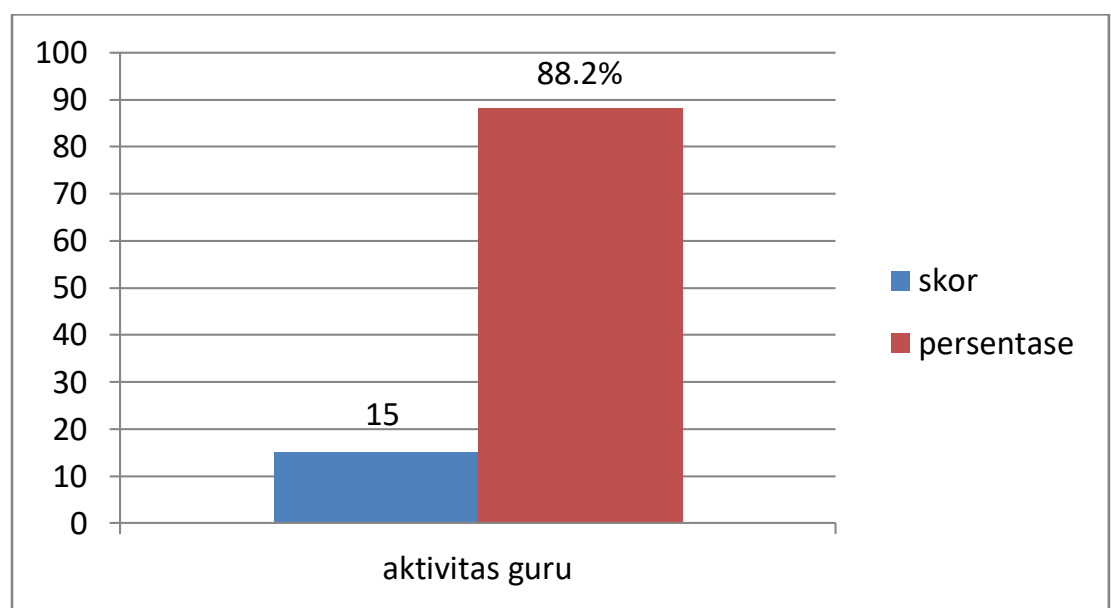

Gambar 2. Hasil Observasi Aktivitas Guru Siklus II

Berdasarkan tabel di atas, dapat dijelaskan bahwa aktivitas guru dalam menerapkan model pembelajaran pada siklus II mencapai skor 15 atau sebesar 88,2\%. Hal ini menunjukkan bahwa aktivitas guru selama pembelajaran pada siklus II meningkat bila dibandingkan pada siklus I.

\section{Aktivitas Siswa Selama KBM}

Observasi aktivitas siswa selama kegiatan pembelajaran dilakukan oleh observer dengan menggunakan instrument lembar observasi aktivitas siswa. Hasil observasi aktivitas siswa siklus I dapat dilihat pada gambar grafik berikut:

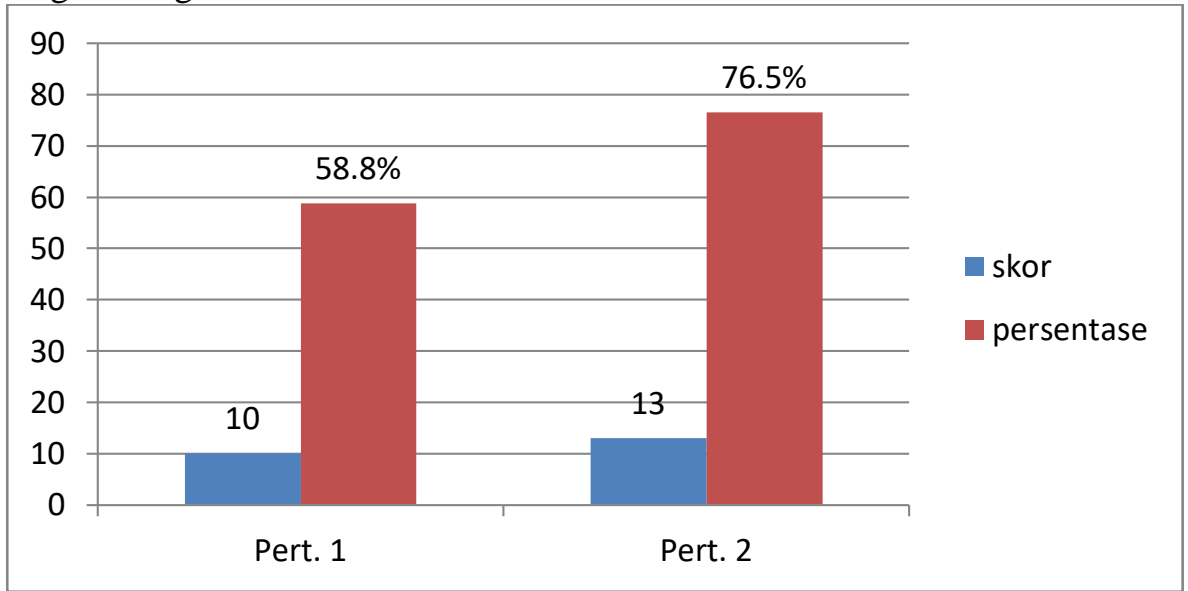

Gambar 3. Hasil Observasi Aktivitas Siswa Siklus I

Berdasarkan grafik di atas dapat dijelaskan bahwa presentase hasil observasi aktivitas siswa pada pertemuan pertama adalah $58,8 \%$ atau 10 skor mengalami peningkatan menjadi $76,5 \%$ atau 13 skor pada pertemuan kedua.

Observasi aktivitas siswa selama kegiatan pembelajaran dilakukan oleh observer dengan menggunakan instrumen lembar observasi aktivitas siswa. Hasil observasi aktivitas siswa siklus II dapat dilihat pada gambar grafik berikut : 


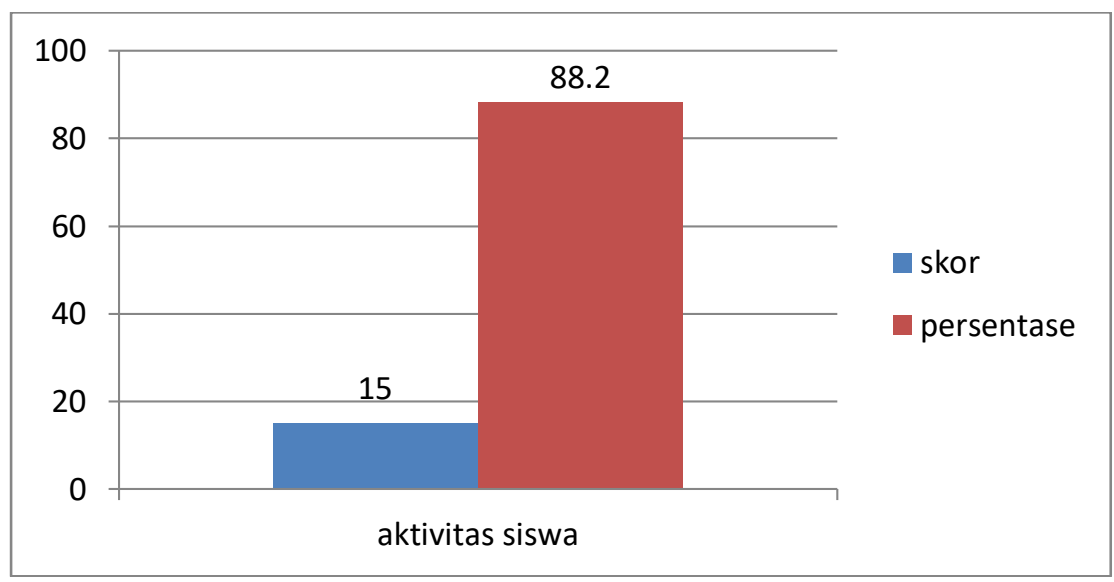

Gambar 4.4. Hasil Observasi Aktivitas Siswa Siklus II

Berdasarkan tabel di atas, dapat dijelaskan hasil observasi aktivitas siswa mencapai 15 skor dengan persentase sebesar $88,2 \%$. Hal ini menunjukkan bahwa aktivitas siswa selama pembelajaran pada siklus II meningkat bila dibandingkan pada siklus I.

\section{Hasil Belajar Siswa}

Setelah materi diajarkan selama dua kali pertemuan, maka tahap selanjutnya adalah tahap evaluasi atau tes siklus I. Evaluasi dilaksanakan dengan tujuan untuk mengetahui keberhasilan pembelajaran siswa setelah pelaksanaan model pembelajaran kooperatif tipe TPS yang dilaksankan pada akhir siklus I. Pembelajaran dalam siklus I bertujuan agar siswa dapat memahami tujuan pembelajaran yang telah ditetapkan. Hasil belajar siswa siklus I menunjukkan bahwa hasil belajar siswa setelah diterapkan model pembelajaran kooperatif tipe TPS mengalami peningkatan dibandingkan dengan pembelajaran sebelum menggunakan model pembelajaran kooperatif tipe TPS. Berdasarkan hasil tes siklus I, secara klasikal siswa yang memperoleh nilai tuntas $(\geq 70)$ sebanyak 13 siswa dari 20 siswa atau sebesar 65\% dengan nilai rata-rata 66,25 namun hasil tersebut belum mencapai standar indikator yang diinginkan.

Berdasarkan tes yang telah dilakukan pada akhir siklus II menunjukkan bahwa hasil belajar siswa mengalami peningkatan dibandingkan dengan hasil belajar pada siklus I. Berdasarkan hasil tes siklus II seperti terlihat pada tabel 4.2. di atas, secara klasikal siswa yang memperoleh nilai tuntas atau $\geq 70$ berjumlah 18 dari 20 siswa atau sebesar $90 \%$ dengan nilai rata-rata 72,3 . Hasil tersebut telah mencapai standar KKM yang ditetapkan di sekolah.

Berdasarkan hasil evaluasi atau tes tindakan siklus II terlihat bahwa hasil belajar PKn siswa kelas III SD Negeri 2 Laloeha, secara klasikal mengalami peningkatan bila dibandingkan dengan siklus I. Pada siklus I persentase ketuntasan hasil belajar siswa sebesar $65 \%$ sedangkan pada siklus II mencapai 90\%.

\section{Pembahasan}

Hasil belajar diperoleh dengan melakukan evaluasi atau penilaian untuk mengukur tingkat penguasaan siswa terhadap materi pelajaran. Evaluasi atau tes yang diberikan setelah pembelajaran usai. Menurut Arends (dalam Trianto, 2010:81) penerapan model pembelajaran kooperatif tipe TPS dapat mengendalikan kelas secara keseluruhan, dapat memberi siswa lebih banyak waktu untuk berpikir, untuk merespon dan saling membantu sehingga dapat meningkatkan hasil belajar siswa.

Berdasarkan hasil penelitian yang telah dilakukan menunjukkan bahwa dengan menerapkan model pembelajaran kooperatif tipe TPS dalam pembelajaran memiliki dampak positif dalam meningkatkan hasil belajar siswa pada materi Norma yang Berlaku di Masyarakat di kelas III SD Negeri 2 Laloeha. Hal ini dapat dilihat dari adanya peningkatan hasil belajar siswa pada setiap siklus, pada siklus I jumlah siswa yang tuntas adalah 13 siswa dengan persentase sebesar $65 \%$ dan yang tidak tuntas adalah 6 siswa dengan persentase sebesar 35\%. Rata-rata hasil tes siklus I adalah 66,25. Pada siklus II jumlah siswa yang tuntas adalah 18 siswa dengan persentase sebesar $90 \%$ dan 
yang tidak tuntas adalah 1 siswa dengan persentase sebesar 10\%. Rata-rata hasil tes siklus II adalah 72,3 .

Berdasarkan hasil penelitian yang telah dilakukan menunjukkan bahwa dengan menerapkan model pembelajaran kooperatif tipe TPS dalam pembelajaran memiliki dampak positif terhadap peningkatan aktivitas belajar siswa di kelas III SD Negeri 2 Laloeha. Hal ini dapat dilihat dari adanya peningkatan aktivitas belajar siswa pada setiap siklus, nampak bahwa pada siklus I skor aktivitas siswa pertemuan pertama adalah 10 dengan persentase sebesar $58,8 \%$ dan pada pertemuan kedua adalah 13 dengan persentase sebesar 76,5\%. Sedangkan pada siklus II persentase aktivitas belajar siswa mengalami peningkatan. Skor aktivitas belajar siswa siklus II adalah 15 dengan persentase sebesar $88,2 \%$.

Pada penelitian ini, siswa dibagi dalam 8 kelompok. Setiap kelompok terdiri dari dua orang atau berpasangan. Pembentukan kelompok dilakukan dengan mempertimbangkan perbedaan kemampuan serta jenis kelamin. Hal ini sejalan dengan salah satu ciri model pembelajaran kooperatif yang dikemukakan oleh Arends (dalam Trianto 2010:65) menyatakan bahwa kelompok dibentuk dari siswa yang mempunyai kemampuan tinggi, sedang, dan rendah serta bila memungkinkan anggota kelompok berasal dari ras, budaya, suku dan jenis kelamin yang beragam. Analisis hasil observasi aktivitas siswa dalam pembelajaran menunjukkan bahwa pembelajaran dengan penerapan model pembelajaran kooperatif tipe TPS memiliki dampak positif dalam meningkatkan hasil belajar siswa. Hal ini dapat dilihat dari hasil observasi kegiatan belajar siswa dari setiap pertemuan ke pertemuan selanjutnya.

Berdasarkan hasil observasi pada siklus I, kegiatan belajar siswa belum terlaksana dengan baik dan masih terdapat kekurangan-kekurangan yang harus diperbaiki. Berdasarkan kekurangankekurangan pada siklus I, maka penelitian dilanjutkan pada siklus II. Pada siklus II siswa sudah dapat mengikuti pembelajaran dengan lebih baik, hal tersebut dapat dilihat dari meningkatnya hasil observasi siswa yang telah mencapai $88,2 \%$.

Berdasarkan hasil penelitian yang telah dilakukan menunjukkan bahwa dengan menerapkan model pembelajaran kooperatif tipe TPS dalam pembelajaran memiliki dampak positif terhadap peningkatan aktivitas mengajar guru kelas III SD Negeri 2 Laloeha. Hal ini dapat dilihat dari adanya peningkatan aktivitas mengajar guru pada setiap siklus, nampak bahwa pada siklus I skor aktivitas mengajar guru pertemuan pertama adalah 11 dengan persentase sebesar $64,7 \%$ dan pada pertemuan kedua adalah 13 dengan persentase sebesar 76,5\%. Sedangkan pada siklus II persentase aktivitas mengajar guru mengalami peningkatan. Skor aktivitas mengajar guru siklus II adalah 15 dengan persentase sebesar $88,2 \%$.

Analisis hasil observasi aktivitas mengajar guru dalam pembelajaran menunjukkan bahwa pembelajaran dengan penerapan model pembelajaran kooperatif tipe TPS memiliki dampak positif dalam meningkatkan kualitas kegiatan guru. Hal ini terlihat dari hasil observasi kegiatan guru pada setiap pertemuan. Pada siklus I, persentase kegiatan mengajar guru yaitu 64,7\% pada pertemuan pertama dan meningkat menjadi $76,5 \%$ pada pertemuan kedua. Namun disadari masih terdapat kekurangan-kekurangn yang masih perlu diperbaiki, diantaranya: 1) guru menyampaikan materi pelajaran kurang sistematis dan agak cepat, 2) guru tidak membimbing semua siswa yang mengalami kesulitan, 3) guru tidak meminta siswa menanyakan materi pelajaran yang belum dimengerti, 4) guru tidak melibatkan siswa dalam membuat kesimpulan materi pelajaran.

Berdasarkan kekurangan yang ada pada siklus I maka pada siklus II peneliti lebih menitikberatkan perbaikan kekurangan tersebut agar pembelajaran berjalan lancar dan efektif sehingga pada siklus II persentase aktivitas mengajar guru mengalami peningkatan. Ketuntasan belajar siswa mengindikasikan bahwa indikator keberhasilan penelitian yang ditetapkan telah tercapai. Sedangkan hasil observasi terhadap pelaksanaan pembelajaran bisa dikatakan sempurna, yakni seluruh komponen dalam skenario pembelajaran telah dilaksanakan dengan baik sesuai yang diharapkan. Karena kedua indikator telah tercapai, maka hipotesis tindakan telah tercapai yakni: penerapan model pembelajaran kooperatif tipe TPS dapat meningkatkan hasil belajar PKn siswa materi Norma yang Berlaku di Masyarakat di kelas III SD Negeri 2 Laloeha. Dari hasil evaluasi tersebut menunjukan bahwa usaha dan keberhasilan belajar dipengaruhi oleh berbagai faktor. Hal ini sesuai dengan yang dikemukakan oleh Syah (2010:132) bahwa hasil belajar dipengaruhi oleh beberapa faktor yaitu, faktor internal adalah faktor yang berasal dari diri siswa, faktor eksternal 
adalah faktor yang berasal dari luar diri siswa dan faktor pendekatan belajar yaitu jenis upaya belajar yang meliputi strategi dan metode yang digunakan untuk melakukan pembelajaran.

Hasil penelitian menunjukkan bahwa indikator keberhasilan dalam penelitian telah tercapai, maka hipotesis tindakan dalam penelitian ini telah tercapai yaitu penerapan model pembelajaran kooperatif tipe TPS dapat meningkatkan hasil belajar siswa materi pokok Norma yang Berlaku di Masyarakat di Kelas III SD Negeri 2 Laloeha. Menurut Trianto (2010:21) bahwa model pembelajaran kooperatif tipe TPS ini memberikan manfaat yang sangat besar terhadap siswa dalam hal mengembangkan keterampilan sosial siswa. Keterampilan yang dimaksud antara lain: 1) berbagi tugas di antara anggota sekelompoknya; 2) mengaktifkan siswa dalam mengeluarkan pendapat sperti bertanya dan menjawab pertanyaan serta menghargai pendapat orang lain dan mau menjelaskan ide atau pendapatnya; dan 3) menumbuhkan kemampuan kerja sama siswa dalam kelompok.

\section{Simpulan}

1. Aktivitas mengajar guru pada materi Norma yang Berlaku di Masyarakat dapat ditingkatkan melalui penerapan model pembelajaran kooperatif tipe Think Pair Share (TPS) di kelas III SD Negeri 2 Laloeha Kabupaten Kolaka. Hal ini dilihat dari persentase aktivitas mengajar guru siklus I pertemuan pertama sebesar $64,7 \%$ dan pertemuan kedua sebesar $76,5 \%$ sedangkan pada siklus II mencapai $88,2 \%$.

2. Aktivitas belajar siswa pada materi Norma yang Berlaku di Masyarakat dapat ditingkatkan melalui penerapan model pembelajaran kooperatif tipe Think Pair Share (TPS) di kelas III SD Negeri 2 Laloeha Kabupaten Kolaka. Hal ini dilihat dari persentase aktivitas belajar siswa siklus I pertemuan pertama sebesar $58,8 \%$ dan pertemuan kedua sebesar $76,5 \%$ sedangkan pada siklus II mencapai $88,2 \%$.

3. Hasil belajar PKn siswa pada materi Norma yang Berlaku di Masyarakat dapat ditingkatkan melalui penerapan model pembelajaran kooperatif tipe Think Pair Share (TPS) di kelas III SD Negeri 2 Laloeha Kabupaten Kolaka. Hal ini dapat dilihat dari ketuntasan hasil belajar siswa pada siklus I mencapai 13 orang atau sebesar $65 \%$ dengan nilai rata-rata 66,25 dan pada siklus II mencapai 18 orang atau sebesar $90 \%$ dengan nilai rata-rata 72,3 .

\section{Daftar Pustaka}

Amri S., 2013. Model Pembelajaran Dalam Kurikulum 2013. Jakarta: Prestasi Pustakaraya.

Hartina, 2010. Upaya Meningkatkan Hasil Belajar PKn Siswa Kelas IV SD Negeri Lalombaa Pada Materi Sistem Pemerintahan Kabupaten dan Kota Melalui Penerapan Pembelajaran Kooperatif Tipe TPS. Skripsi. FKIP. UHO. Kendari.

Nawariah, 2014. Penerapan Model Pembelajaran Kooperatif Tipe Think-Pair-Share (TPS) untuk Meningkatkan Hasil Belajar PKn Siswa pada Materi Keputusan Bersama di Kelas III SD Negeri 05 Kendari Barat. Skripsi. FKIP. UHO. Kendari.

Suparno P., 2008. Riset Tindakan untuk Pendidik. Jakarta: Grasindo.

Syah, Muhibin. 2010. Psikologi Pendidikan dengan Pendekatan Baru. Bandung: Remaja Rosdakarya

Trianto, 2010. Mendesain Model Pembelajaran Inovatif-Progresif. Surabaya: Kharisma Putra Utama. 